\title{
Alternative Treatments of Postpartum Uterine Diseases in Dairy Cows
}

\author{
Lefebvre $\mathrm{RC}^{1 *}$, Ali Torabi ${ }^{2}$, Ali Bazzazan ${ }^{3}$ and Stock $\mathrm{AE}^{3}$ \\ ${ }^{1}$ Division of Health Education, Memorial Hospital of Rhode Island, Pawtucket, USA \\ ${ }^{2}$ Full Professor, University of Tehran, Iran \\ ${ }^{3}$ Postgraduate Student, University of Montreal, Canada
}

${ }^{\star}$ Corresponding author: Lefebvre RC, Division of Health Education, Memorial Hospital of Rhode Island, Pawtucket, USA; E-mail: rejean.lefebvre@umontreal.ca

Received: September 09, 2021; Accepted: September 23, 2021; Published: September 27, 2021

\begin{abstract}
The ultimate goal of treating postpartum uterine diseases (PUDs) in dairy cows is to reach clinical cure in a reasonable amount of time and to improve reproductive performance while minimizing milk and meat residue issues, and consequently, reducing economic losses. Even though some local antibiotic treatments are effective to mitigate the effect of PUDs, veterinarians will eventually use more natural alternatives to meet the global context of antimicrobial resistance and protect human and animal health. Research advances have improved our understanding of the uterine involution and the ethiopathology of the different pathological postpartum conditions in dairy cows. This has opened new therapeutic and preventive approach, however, most recent research is still in the early experimental stages and under scrutiny. The aim of the present article is to review non-antibiotic approaches used to treat or prevent PUDs in dairy cows. The authors include: Chitosan microparticles, essential oils, mannose, bacteriophages, dextrose, paraffin, ozone, probiotics, antiseptics, homeopathy, apitherapy, vaccines, pegbovigrastim, recombinant IL-8, and genomic selection.
\end{abstract}

Keywords: Postpartum uterine diseases, Dairy cows, Reproductive performance, Alternative treatments, Non-antibiotic

\section{Introduction}

The ultimate goal of treating postpartum uterine diseases (PUDs) in dairy cows is to reach clinical cure in a reasonable amount of time and to improve reproductive performance while minimizing milk and meat residue issues, and consequently, reducing economic losses. Acute puerperal metritis in cows is usually treated with systemic antimicrobial drugs (cephalosporin, or tetracycline, ceftiofur, penicillin) and a fluid therapy in severe cases [1]. Because of concerns about antibiotic resistance and residues, some veterinarians advocate waiting $24 \mathrm{~h}$ to $48 \mathrm{~h}$ before instituting an anti-microbial therapy, thus allowing a spontaneous cure of about $30 \%$ [2]. In severe cases, this is frequently not advised in order to protect the welfare of the animal. Indeed, manipulation of the uterus and drainage of the fetid watery red-brown discharge are not recommended because of the risk of perforation of the friable and painful uterine wall and bacteremia [3]. There is no evidence of improvement of the clinical condition or reproductive efficiency with other treatments, such as estrogen [4] which is now illegal in many countries, or oral calcium [5]. In cases of pyometra, PGF2a or its analogue [6] is the treatment of choice, allowing luteolysis of the persistent corpus luteum, expulsion of uterine exudates, and reduction of the bacterial load in $90 \%$ of cases with a recurrence rate of about $10 \%$ [7], in which case the PGF2a treatment should be repeated. In refractory cases, a local antibiotic may be added to the second injection of PGF2a. Veterinarians need to remember that the use of intrauterine nitrofurazone infusion has been known to reduce conception rates. Endometritis (clinical and subclinical) is most often treated with intrauterine infusion of a specific formulation of cephapirin (Metricure, Merk) which has beneficial effects on clinical cure and subsequent reproductive performance [8-12]. Although prostaglandins are still used for treatment and prevention of endometritis, there is no evidence of efficacy neither for improving reproductive efficiency nor for reducing its incidence [2], Lefebvre and Stock 2012). However, this hormone is essential in synchronization protocols for controlled breeding programs. The aim of the present article is to review non-antibiotic approaches used to treat or prevent PUDs in dairy cows.

\section{Alternative Medicine}

Veterinarians could substitute antibiotics for natural alternatives, especially in the global context of antimicrobial resistance and given the World Health Organization's position on the use of medically important antibiotics and the One Health program. Despite the well documented detrimental impact of PUDs on the cow reproductive health, treatment and prevention practices of farmers are not always recorded and consistent. For example, [13] have shown significant disparity as to how farmers treat metritis. To mitigate the impact of PUDs, several non-antimicrobial therapies to treat or prevent uterine diseases have been proposed. However, most of them are still in the early experimental stages and under scrutiny. In addition, the scientific merit of most in vivo studies seems to be compromised by experimental factors: absence of precise clinical definition, inconsistencies of outcomes, lack of negative controls, insufficient numbers of animals per treatment group, use of inadequate or rebutted 
diagnostic methods, disparity in the studied population, lack of randomization, and faulty experimental design. However, these studies carry forward the limits of our understanding and provide a different perspective on the treatments of PUDs in dairy cows. These new approaches include: Chitosan microparticles, essential oils, mannose, bacteriophages, dextrose, paraffin, ozone, probiotics, antiseptics, homeopathy, apitherapy, vaccines, pegbovigrastim, recombinant IL-8, and genomic selection. These alternative therapies attempt to improve the avoidance (chitosan, mannose, dextrose), the tolerance (probiotic, paraffin, and ozone), and resistance (pegbovigrastim, recombinant IL8 , and genomic selection) of defense mechanisms in the genital tract of dairy cows.

\section{Alternative Therapy for PUDs}

Chitosan is recognized by the FDA and synthesized from chitin of the exoskeleton of arthropods and cell walls of certain fungi and yeast and has a large antimicrobial spectrum in neutral and acidic environment [14]. The normal $\mathrm{pH}$ of the cow's genital tract is neutral between 6.84 and 7.51 [15]. The product claims to improve the cow's resistance by reducing the uterine bacterial load. More specifically, the antimicrobial activity of chitosan microparticles is associated with the disruption of the bacterial cell membranes by interactions with the outer membrane protein A (OmpA) leading to cell death [14]. The cows with metritis were administered $24 \mathrm{~g}$ (in $40 \mathrm{ml}$ of sterile distilled water) of chitosan particles in the uterus for 3 days (D0; day of diagnosis, D2, and D4), and compared to ceftiofur crystalline-free treatment $(6.6 \mathrm{mg} / \mathrm{kg} \mathrm{SC}$ in the base of the ear at D0 and D3) or no treatment at all as the control group [16]. No improvement of clinical sings was measured. However, the treatment decreased milk production, reproductive performance (conception rate at first $\mathrm{AI}$, and pregnancy rate at $300 \mathrm{DIM}$ ), and survival rate of treated cows compared to the control group [16]. Case definition and the number of local treatments may have rendered the results even more uncertain. Therefore, intrauterine use of chitosan is not recommended in dairy cows.

Essential oils (about 3000) are volatile substances naturally produced by plants as secondary metabolites and are known for their antibacterial, antifungal, insecticidal, and antiviral properties. The special biological properties and fragrance of essential oils are in a great portion due to terpenes and phenylpropanoids [17]. An important point to know is that essential oils have several compounds and their bioactivities result from the complex interactions between the different classes of compounds. Essential oils have antioxidative, anti-inflammatory, and antimicrobial properties making them good candidates in infectious process like UPDs [18]. A compound of certified organic essential oils (Optimum UterFlush, Van Beek Natural Science, Orange City, IA, $\mathrm{n}=107$ ) was infused every other day for a total of 3 times between 1 and 12 DIM in the uterus of puerperal toxic metritis dairy cows and the results were compared to the intrauterine iodine povidone infusion group ( $\mathrm{n}=113$ ), and the control group (health cows, $\mathrm{n}=400$ ) in organic farms [19]. The first service conception rates were $23 \%, 37 \%$, and $38 \%$ in cows infused with iodine, the essential oils and the control group of healthy cows respectively $(\mathrm{p}=0.05)$. At 150 DIM, $75 \%, 31.1 \%$, and $44.8 \%$ were pregnant in the healthy, iodine, and Optimum Uterflush groups respectively. The survival analyses indicated a tendency to shorten the interval from calving to first AI $(\mathrm{P}=0.08)$. The odds of pregnancy at $150 \mathrm{DIM}$ for cows with Optimum Uterflush group was 1.81 times the odds of cows infused with iodine. In the study, all cows received intravenous calcium and hypertonic saline in addition to oral aspirin. The effect of Optimum UterFlush was not tested on healthy cows. The first results are very encouraging and further research on a larger scale is needed.

\section{Carbohydrate}

Three rationales have motivated researchers to use sugars as intrauterine remedy for postpartum uterine infections: 1) sugars disrupt attachment of bacteria to tissues, 2) sugars inhibit microbial growth, and 3) sugars are hypertonic and attract fluid in the uterus and facilitate eviction of debris and bacteria when the uterine cervix opens. Often lectins present on the surface of the infectious organism bind to complementary carbohydrates on the surface of the host tissues. In this way, the pathogen is not washed away by natural cleansing system of the host. Furthermore, the adhesion represents a good source of nutrition, facilitates the delivery of the toxins, and eventually the penetration of the bacteria into the tissues. The lectins present elongated multi-protein appendages with sugars (typically saccharides) on the surface of bacteria increase infectiousness (ex. fimH for E. coli) for the organism [20]. Anti-adhesion therapy consists in the inhibition of these lectins by suitable carbohydrates for prevention or treatment of microbial diseases. Mannose [21] and $50 \%$ dextrose [22-25] have been tested in cows with metritis and endometritis. Since the publication of the ability of mannose to block growth of E. coli in human wounds and to inhibit its adhesion on endometrial cells in mares with endometritis [26], research has been done in cows with PUDs. Adhesion of pathogenic organisms to host tissues is often the prerequisite for the initiation of infectious diseases. By inhibiting bacterial adhesion to the cell membrane (like endometrial cells), the risk of initiating infection should be lower. The hyperosmotic effect of the high concentration of sugar may also inhibit growth by breaking down bacterial membrane of bacteria. Mannose was used to reduce the risk of metritis in dairy cows [27] by administration of $50 \mathrm{~g}$ of sugar intrauterine 2 days after calving. The treatment was not successful in improving uterine health in treated cows compared to those receiving the placebo. Similarly, $200 \mathrm{~mL}$ of $50 \%$ dextrose solution infused intrauterine of endometritis cows at about 30 DIM did not improve neither the cure rate, the first conception rate, nor the calving-to-conception interval [22,23]. However, the cure rate of endometritis was improved with the dextrose treatment in other studies [25]. Nevertheless, it improved the median of days open compared to systemic treatment ceftiofur or no treatment at all (control). Also, the resulting accumulation of transudate in the uterus after infusion of dextrose is not well documented. Thus far, treatment of metritis and endometritis using 50\% solution of dextrose remains to have sound results.

\section{Parafin}

Intrauterine infusion of liquid paraffin for endometritis has been proposed to increase the resilience of the uterus in the postpartum period. Unfortunately, the condition of cows with endometritis 
infused with $100 \mathrm{ml}$ at around 30 DIM did not improve, but instead, sustained a reduction in their reproductive performance [22]. Without additional studies, liquid paraffin should not be considered, as an option for the treatment of endometritis in dairy cows.

\section{Ozone}

Ozone is a gas consisting of 3 atoms of oxygen in a dynamic unstable structure essential for life on earth due to its ability to absorb wavelengths of harmful UV radiation coming from spectra of sunlight [28]. Because ozone manifests strong bactericidal, fungicidal, viricidal, yeasticidal, and protozocidal properties, it is used in medical therapies, and is available in different types of products: vegetal ozoned oil with emollient, cicatrizing, antibacterial, and hygienic compounds in several forms (creams, gasses, syringes, paillettes, foam, and boluses) [29]. Ozone inhibits growth of bacteria by damaging the capsule and cell membrane through the activity of peroxidases, and may block replication of bacterial DNA, and often acts as a supportive therapy in infectious diseases. Grampositive bacteria seem more sensitive to ozone than Gram-negative bacteria. The most important activity of ozone is probably the synthesis of cell membrane enzymes like superoxide dismutase, catalase, and glutathione peroxidase to counter the damaging effects of $\mathrm{O} 2$ free radicals [30]. It reduces the cascade of pro-inflammation by promoting immunosuppressive cytokines like IL-10 and TNFß1 by neutrophils, monocytes, and lymphocytes [31]. The therapeutic efficacy of ozone is most likely dependent on the strength of the oxidative stress produced. Moderate oxidative stress activates nuclear transcriptional factors ( $\mathrm{NrF} 2)$ suppressing NFkB and stimulating inflammatory responses. Ozone has been used to prevent [32] and treat $[33,34]$ endometritis and metritis respectively with some positive effect. Even though ozone therapy is used in several human conditions (autohemotherapy, antineoplastic therapy, obstructive arterial diseases, macular degeneration, autoimmune diseases, and diabetes), it still not accepted yet as medical treatment in all countries [31]. In terms of efficacy of ozone in dairy cows with endometritis, the low number of animals in studies does not allow readers to draw clear conclusion.

\section{Bacteriophage}

The use of bacteriophages and phage-derived endolysins may represent an alternative treatment for PUDs in dairy cows [35]. Bacteriophages are host specific viruses of particular species or strains of bacteria. Phages produce endolysin which digests the bacterial wall, enters the cells and integrates the genome (prophage) of the host cell and replicates, resulting in lysis of the cell wall [36] in the biofilms produced by certain bacteria such as E. coli, T. pyogenes, coagulase-negative staphylococcus and S. aureus [37]. Intrauterine infusion of bacteriophages specific to E. coli and T. pyogenes 2 days prepartum and postpartum have shown no effect on uterine health and reproductive performance, instead, have increased the incidence of retained fetal membranes and metritis [21]. As for paraffin, the use of bacteriophages in PUDs in dairy cows is not recommended and more research is needed.

\section{Probiotics}

Probiotics are defined as live microorganisms that, when administered in adequate amounts, confer a health benefit on the host. Probiotic products include probiotic-containing drugs, medical and conventional foods, dietary supplements, and animal fodder. However, it excludes microbial transplants, fermented foods, dead microbes, and microbial products such as protein, polysaccharide, and nucleotide components. Probiotics work by producing substances that have desirable effects on the body like improving the immune response or maintaining a healthy microbiome [38]. In humans, probiotics have shown promises for the prevention of antibiotic-associated diarrhea (Clostridium difficile), necrotizing enterocolitis, sepsis, and for treatment of infant colic, periodontal diseases, and ulcerative colitis. Prebiotics are not the same as probiotics since prebiotics are food components that selectively stimulate the growth or activity of desirable microorganisms. Probiotics may contain a variety of microorganisms, but one of the most common is Lactobacillus which is the major member of the vaginal microbiome in women. In dairy cows, several doses of cocktails of lactic acid were infused in the vagina (before calving) and in the uterus (after calving) to measure the effect on the incidence of metritis and endometritis [39-41]. Treatments with the lactic acid cocktails reduced the incidence of metritis and endometritis, improved vaginal mucus secretion of immunoglobulin $\mathrm{A}$, and decreased the inflammatory response by reducing neutrophil gene expression. Therefore, intravaginal and intrauterine infusion of probiotics seem effective in reducing the incidence of PUDs. The probiotic functionality and efficacy are species specific and therefore, different cocktails may have different effects.

\section{Apitherapy}

Another alternative way to treat PUDs is apitherapy. Honey products have been used extensively since ancient times for antiputrefactive (mommies), antiseptics, cicatrizant, anti-inflammatory, antimicrobial, antioxidant agents [42], and antibiofilm activities $[43,44]$. It is an influential antioxidant and a free radical scavenger. Nonetheless, for several decades now, modern medicine, propelled by new developments and the wide applications of antibiotics, in which the honey as medical treatment has be sunk into oblivion. Given the repeated occurrence of antibiotic resistance, there has been renewed interest in the medical applications of honey products (propolis, venom, royal jelly, venom, and pollen) for livestock. The active components of honey, such as glucose, fructose, flavonoids, polyphenols, and organic acids are largely responsible for its therapeutic activity. For example, flavonoids found in honey have been shown to induce apoptosis and prevent the release of IL-1ß, Il-6, TNFa, iNOSm and Cox-2 [45]. The propolis has antifungal properties and can be used as an antibiofilm [46]. Honey possesses therapeutic potential and its antimicrobial activity is widely documented as a large number of in vitro studies of MIC and MBC confirmed its broad-spectrum antimicrobial properties [47]. The immunomodulatory response to honey products also manifests itself in the activation of lymphocytic function, the activation of macrophages, and the stimulation of cytokines release by monocytes [48]. AbdulHafeez et al. (2019) infused $100 \mathrm{ml}$ of 70\% Egyptian cotton honey for 3 consecutive days in the uterus of repeat breeder dairy cows $(n=16)$ with purulent vaginal discharge unresponsive to standard antibiotherapies and obtained $75 \%$ conception rate at first insemination after treatment. However, the small number of animals in the study does not allow us to draw any definite conclusions. 
Homeopathy was introduced by Samuel Hahnemann around 1797 as a new method to treat diseases with dilute remedies. There are 3 major fundamental principles of homeopathy: 1) law of similia, 2) law of simplex (the single remedy), and 3) law of minimum. The law of similia means "like cures like", the medicine must have the capability of producing similar symptoms of the disease to cure a person. Hahnemann stated that only one single and simple medicinal substance is to be administered in a given case of time. The reason for this is that if more than one remedy is used, the doctor will never know which element was curative and the different ingredients may even result in interactions that may have adverse effects in the body. The third law is probably the most debated. Under this principle, the quantity of medicine given to a patient is minimum and appropriate for a gentle remedial effect to avoid any aggravation.

In the scientific community and veterinary practice, the use of homeopathy in food-producing animals is controversial even though it is common practice on organic farms. As the other alternatives, the development of the homeopathy is fueled by overuse of antibiotic in humans and animals which has promoted the antibiotic resistance [49]. The mechanism of action of homeopathic drugs are not known however for example, Lachesis is used for several inflammatory conditions including uterine infection because it is believed that it stimulates the local immune defense and helps the mucosa to regenerate $[50,51]$. In ruminants, clinical trails reported on uterine infections in dairy cows [52]. Homeopathic studies on fertility addressed especially the peripartum period (retained placenta, endometritis) and almost exclusively in a preventive instead of the therapeutic approach. In a randomized, controlled, and double-blinded clinical trial, [53] compared three different mixed formulas of homeopathic remedies (Traumeel, Lachies, and Carduus administered IM) in dairy cows with clinical endometritis at calving, 7 to 13 DIM, 14 to 20 DIM, and 21 to 27 DIM. In contrast to the second law, the researchers did not use an individualized therapy. The homeopathic treatments were not effective in preventing endometritis or improving the metabolic condition and the reproductive performance. Another randomized, controlled, and blinded trial with 105 cows with compound remedies resulted in a significant reduction of noncycling cows compared to the control group [54]. Homeopathic treatments reduced significantly the number of days to pregnancy [55] and fewer services per conception [50]. No trial was repeated in a comparative manner. Due to low number and quality of studies available (high risk of bias), there are limited evidence for statistical difference between homeopathic remedies and the control.

Antiseptics (chlorhexidine, propylene glycol, lugol's iodine, iodine, polyvinyl-pyrrolidon-iodine, formaldehyde, and Betadine solutions) have been routinely used in veterinary practice for many years to treat postpartum uterine infections in dairy cows [56,57]. It was postulated that intrauterine infusion of irritating antiseptics would trigger an acute inflammation transforming chronic endometritis into an acute condition (local irritation) by stimulating the uterine immune defense [58]. Antiseptics have also an microbiocidal effect. In addition, it is expected that a local condition like endometritis could be treated locally (intrauterine infusion). Intrauterine infusions of $2 \%$ and $4 \%$ polycondensated $\mathrm{m}$-cresolsulphuric acid formaldehyde in dairy cows with endometritis between 22 and 28 DIM did not improve the conception rate compared to the prostaglandin treatment $[59,60]$. Similar results were obtained with intrauterine infusion of $2 \%$ polyvinylpyrrolidone-iodine at 35 DIM [57], $\mathrm{n}=531$ ) which was detrimental to reproductive efficiency. However, no detrimental effect was measured in cows without endometritis. [61] infused in the uterus $100 \mathrm{ml}$ of Betadine without improvement of the reproductive performance compared to intrauterine infusion of antibiotics or intramuscular prostaglandins. The reduction of the reproductive performance with intrauterine infusion of antiseptics may be associated with the irritating effect on the endometrium which could have caused fibrosis. Another concern about the infusion of iodine derivatives into the uterus is the significant increase of iodine concentrations in the milk $[62,63]$. In conclusion, irritation of the endometrium by intrauterine infusion of antiseptics has a negative effect on uterine defense and reduces self-healing ability. Unfortunately, several studies are typically lacking negative controls and insufficient numbers of animals per treatment group as well as a faulty experimental design with absence of randomization.

\section{Alternative Prevention to Reduce PUD Incidence Rates}

In the past decade, research on innate immunity has provided a better understanding of the PUD etiopathology in dairy cows, but the potential role of adaptive immunity in postpartum uterine defense is not yet perfectly understood and the production of a vaccine against metritis is still in the early stages of development [64,65]. The lymphocyte population composed of B-cells, T-cells, and NK cells were found in endometrium of cows [16]. Authors noted that the B-lymphocyte population in water buffaloes was widely distributed through the endometrium, the stroma, and the luminal and glandular epithelium, and the myometrium compared to the population of CD4, CD8, and NK cells. At the moment, four studies have used different vaccine formulations targeting $E$. coli, and T. pyogenes as major pathogens with or without virulence factors (FimH, Leukotoxin, pyolosin), and Bacteroides and streptococcus uberis as secondary bacteria [66-69]. Of the four studies, only one measured the serological response based on blood levels of IgG specific to the antigens utilized in the vaccine formulation [67]. Inoculations of the vaccines were done with whole cells orally, intravaginally, or subcutaneously in heifers or cow. Two out of the four studies succeeded in reducing the incidence of metritis $[67,68]$ and one led to an improvement of reproductive efficiency [67]. In addition, milk production was increased in the first 30 DIM in multiparous cows [68]. The difference in efficacy among these studies may be related to the vaccine formulation, and therefore, more research is warranted to replicate the findings regarding the efficacy of a vaccine against metritis. Another approach to improve the immune defense of cows in peripartum has been the use of Pegbovigrastim. This molecule is a recombinant bovine granulocyte colony-stimulating factor (G-CSF) which is a hematopoietic growth factor that stimulates the production and differentiation of neutrophils by the bone marrow [70]. Subcutaneously administered pegbovigrastim 7 days before the expected calving date and 1 day after calving increased of circulating neutrophils counts but did not decrease the incidence of PUDs [71] forcing its removal from the market. A similar strategy using recombinant IL-8 (rbIL-8) was 
proposed to reduce PUDs. The IL-8 is a pro-inflammatory cytokine which attracts and activates neutrophils into the inflammatory tissues, stimulates their chemotaxis, and increases phagocytosis and killing ability [72]. Intrauterine infusions of high and low doses of rbIL-8 within $12 \mathrm{~h}$ of calving in dairy cows were adequate to decrease metritis incidence and increase milk production compared to control cows $[73,74]$. If large studies confirm these preliminary results, rbIL- 8 could have a promising impact on dairy farms.

The best way to increase efficiency of farms is to prevent diseases. Genomic and genetic studies attempted to validate genomic prediction analysis by taking advantage of the disparity between the worst and the best herds in the incidence of reported diseases [75] and incorporating the data in a selection program. For a long time, practitioners have observed large differences in PUD incidence rate among herds. Nonetheless, the heritability of uterine diseases is low. Even though genetic heritability for metritis $(0.05)$ and endometritis (0.04) is actually very low, geneticists used Bayesian statistical models and high-density SNP panels to estimate genomic predictive values of uterine health traits (PUDs) in Holstein cows in a more efficient way [76]. Taking into account the increase in genomic testing, these tools may soon become part of a preventive program against PUDs [77].

\section{Conclusion}

Despite the documented positive impact of intrauterine infusion of antibiotics for the treatment of PUDs in dairy cows, the global context of antimicrobial resistance compels veterinarians to substitute antibiotics with alternatives to mitigate the impact of PUDs reproductive performance and productivity of cows. Several non-antimicrobial therapies to treat and prevent PUDs have been proposed. However, most of them are still in the early experimental stages.

\section{References}

1. Gilbert RO (2016) Management of reproductive disease in dairy cows. Vet Clin Food Anim 32: 387-410. [crossref]

2. Haimerl P, Arlt S, Heuwieser W (2012) Evidence-based medicine: quality and comparability of clinical trials investigating the efficacy of prostaglandin $F(2 a)$ for the treatment of bovine endometritis. J Dairy Res 79: 287-296. [crossref]

3. Gilbert RO, Schwark WS (1992) Pharmacologic considerations in the management of peripartum conditions of the cow. Vet Clin North Am Food Anim Pract 8: 29-56. [crossref]

4. Risco CA and Hermandez J. (2003) Comparison of ceftiofur hydrochloride and estradiol cypionate for metritis prevention and reproductive performance in dairy cows affected with retained fetal membrane. Theriogenology 60: 47-58. [crossref]

5. Hermandez J, Risco CA, Elliot JB (1999) Effect of oral administration of a calcium chloride gel on blood mineral concentration, parturient disorders, reproductive performance, and milk production of dairy cows with retained fetal membranes. $J$ Am Vet Med Assoc 215: 72-76. [crossref]

6. El-Tahawy Ael G and Fahmy MM (2011) Partial budgeting assessment of the treatment of pyometra, follicular cyst, and ovarian inactivity causing postpartum anoestrus in dairy cows. Res Vet Sci 90: 44-50.

7. Zwald NR, Weigel KA, Chang YM, Welp RD, et al. (2004) Genetic selection for health traits using producer-recorded data. I Incidence rates, heritability estimates, and sire breeding values. J Dairy Sci 87: 4287-4294. [crossref]

8. Kasimanickam R, Duffield TF, Foster RA, Gartley CJ, et al. (2004) Endometrial cytology and ultrasonography for the detection of subclinical endometritis in postpartum dairy cows. Theriogenology 62: 9-23. [crossref]
9. LeBlanc SJ, Duffield TF, Leslie KE, et al. (2002) The effect of treatment of clinical endometritis on reproductive performance in dairy cows. J Dairy Sci 85: 2237-2249. [crossref]

10. Tison N, Bouchard E, DesCôteaux L, Lefebvre R (2017) Effectiveness of intrauterine treatment with cephapirin in dairy cows with purulent vaginal discharge. Theriogenology 89: 305-317. [crossref]

11. Runciman DI, Anderson GA, Malmo I et al. (2008) Effect of intrauterine treatment with cephapirin on the reproductive performance of seasonally calving dairy cows at risk of endometritis following periparturient disease. Aust Vet J 86: 250-258. [crossref]

12. Denis-Robichaud J and Dubuc J (2015) Randomized clinical trial of intrauterine cephapirin infusion ion dairy cows for the treatment of purulent discharge and cytological endometritis. J Dairy Sci 98: 6856-6864. [crossref]

13. Espadamala A, Pereira R, Pallares P, Lagao A, et al. (2018) Metritis diagnosis and treatment practices in 45 dairy farms in California. J Dairy Sci 101: 9608-9616. [crossref]

14. Jeon SJ, Oh M, Yeo WS, Galvao KN, Jeong KC (2014) Underlying mechanism of antimicrobial activity of chitosan microparticles and implication for the treatment of infectious diseases. Plos One 9: 1-10. [crossref]

15. Ozenc E, Seker E, Dogan N (2010) The effect of bacterial flora on uterine pH values, observed during the estrus cycle, gestation, and in the cases of clinical metritis in cows. J Anim Vet Adv 9: 3000-3004.

16. Oliveira EB, Cunha F, Daetz R, Figueiredo C, et al. (2020) Using chitosan microparticles to treat metritis in lactating dairy cows. J Dairy Sci 103: 7377-7391.

17. Raut JS, Karuppayil SM (2014) Review A status review on the medicinal properties. Industrial Crops and Products 62: 250-264.

18. Burt S (2004) Essential oils: their antimicrobial properties and potential applications in foods: a review. Int J Food Microbiol 94: 223-253.

19. Pinedo PJ, Velez JS, Bothe H, Pineiro JM, Risco CA (2015) Effect of intrauterine infusion of an organic-certified product on uterine health, survival, and fertility of dairy cows with toxic puerperal metritis. J Dairy Sci 98: 3120-3132. [crossref]

20. Sharon $\mathrm{N}$ (2006) Carbohydrates as future anti-adhesion drugs for infectious diseases. Biochimica et Biophysica Acta 1760: 527-537. [crossref]

21. Machado VS, Bicalho ML, Pereira RV, Caixeta LS, et al. (2012) The effect of administration of mannose or bacteriophages on uterine health, and fertility of dairy cows with special focus on Escherichia coli and Arcanobacterium pyogenes. J Dairy Sci 95: 3100-3109. [crossref]

22. Ahmadi MR, Makki M, Mirzaei A, Gheisari HR (2019) Effects of hypertonic dextrose and paraffin solution as non-antibiotic treatments of clinical endometritis on reproductive performance of high producing dairy cows. Reprod Domest Anim 54: 762-771. [crossref]

23. Machado VS, Oikonomou G, Ganda EK, Milhomem M et al. (2015) The effect of intrauterine infusion of dextrose on clinical endometritis cure rate and reproductive performance of dairy cows. J Dairy Sci 98: 3849-3858. [crossref]

24. Marquivar MG, Barragan AA, Velez JS, Bothe $\mathrm{H}$ et al. (2015) Effect of intrauterine dextrose on reproductive performance of lactating dairy cows diagnosed with purulent vaginal discharge under certified organic management. J Dairy Sci 98: 38763886. [crossref]

25. Brick TA, Schuenemann GM, Bas S, Daniels JB, Pinto CR, Rings, Rajala-Schultzt PJ (2012) Effect of intrauterine dextrose or antibiotic therapy on reproductive performance of lactating dairy cows diagnose with clinical endometritis. J Dairy Sci 95: 1894-1905. [crossref]

26. King SS, Carnevale EM, Nequin LG, Crawford JJ (1998) Inhibition of bacterial endometritis with mannose. J Equine Vet Sci 18: 332-334.

27. Bicalho ML, Machado VS, Oikonimou G, Gilberts RO, Bicalho RC (2012) Association between virulence factors of Escherichia coli, Fusobacterium necrophorum, and Arcanobacterium pyogenes and uterine diseases of dairy cows. Vet Microbiol 157: 125-131. [crossref]

28. Di Paolo N, Bocci V, Gaggioti E (2004) Ozone therapy editorial review. Int J Artif Organs 27: 168-175.

29. Travagli V, Zanardi I, Bocci V (2009) Tropical applications of ozone and ozonated oils as anti-infective agents: an insight into the patent claims. In Recent patents on anti-infective drug discovery 4: 130-142. [crossref] 
30. Mandhare MN, Jagdale DM, Gaikwad PL, Gandhi PS, Kadam VI (2012) Miracle of ozone therapy as an alternative medicine. Int J Pharm Chem Biol Sci 2: 63-71.

31. Sagai M and Bocci V (2011) Mechanisms of action involved on ozone therapy: is healing induced via a mild oxidative stress? Med Gas Res 1: 29-31.

32. Djuricic D, Vince S, Ablondi M, Dobranci T et al. (2012) Intrauterine ozone treatment of retained fetal membrane in Simmental cows. Anim Reprod Sci 134: 119124. [crossref]

33. Escandon BM, Espinoza JS, Perea FP, Quito F et al. (2020) Intrauterine therapy with ozone reduces subclinical endometritis an improves reproductive performance in postpartum dairy cows managed in pasture-based systems. Trop Anim Health Prod 52: 2523-2528. [crossref]

34. Constantin T and Bürjoiu IA (2016) Preliminary study on ozone therapy in postpartum endometritis of dairy cows. Agriculture and Agricultural Science Procedia. 10: 384-389.

35. Bicalho RC, Santos TM, Gilbert RO, Caixeta LS, et al. (2010) Susceptibility of Escherichia coli isolated from uteri of postpartum dairy cows to antibiotic and environmental bacteriophages. Part I: isolation and lytic activity estimation of bacteriophages. J Dairy Sci 93: 93-104. [crossref]

36. Kutter E, Sulakvelidze A (2004) Bacteriophages: Biologiy and Applications. 2004. CRC Press Boca Raton, Florida ISBN: 9780849313363.

37. Chan BK and Abedon ST (2015) Bacteriophages and their enzymes in biofilm control. Curr Pharm Des 21:85-89. [crossref]

38. Sanders MA (2015) Probiotic in 2015: their scope and use. J Clin Gastroenterol 49: S1-S5. [crossref]

39. Deng Q, Odhiambo JF, Farooq U, Dunn SM, et al. (2015) Intravaginal lactic acid bacteria modulated local and systemic immune responses and lowered the incidence of uterine infections in periparturient dairy cows. Plos One 10: e0124167. [crossref]

40. Genis S, Cerri RLA, Bach A, Silper BF, et al. (2018) Pre-calving intravaginal administration of lactic acid bacteria reduces metritis prevalence and regulates blood neutrophil gene expression after calving in dairy cattle. Front Vet Sci 5: 135-141. [crossref]

41. Ametaj BN, Iqbal S, Selami F, Odhiambo JF, et al. (2014) Intravaginal administration of lactic acid bacteria modulated the incidence of purulent vaginal discharges, plasma haptoglobin concentrations, and milk production in dairy cows. Res Vet Sci 96: 365370. [crossref]

42. Pasupuleti VR, Sammugam L, Ramesh N, Gan SH (2017) Honey, propolis, and Royal Jelly: a comprehensive review of their biological actions and health benefits. Oxidative Medicine and Cellular longevity. 2017: 21-42. [crossref]

43. Zine EL Abidne K, Bouabdellalh B (201) Dignosis and treatment of endometritis with intra-uterine infusion of a solution of honey $70 \%$ in mares. J Vet Sci Technol 9: 1000499.

44. Shaun J, Duval M, Chan FT, Ferris W, SlingerR (2011) Methylglyoxal: active agent of manuka honey in vitro activity against bacterial biofilms. Inter Form Allergy and Rhinology 1-7.

45. Erejuwa OO, Sulaiman SA, Wahab MSA (2014) Effects of honey and its mechanisms of action on the development and progression of cancer. Molecules 19:2497-2522. [crossref]

46. Capoci LRG, Bonfim-Mendoça P, Arita GS, et al. (2015) Propolis in an efficient fungicide and inhibitor of biofilm production by vaginal Candida albican. Evidencebased. Complementary and alternative medicine. 2015:9-15. [crossref]

47. Ameer AA, Abdul-Hafeez MM, Sayed SM et al. (2015) Minimum inhibitory and bactericidal concentrations (MIC, MBC) of honey and bee propolis against multidrug resistant staphylococcus sp. Isolated from bovine clinical mastitis. Global J Sci Frontier Res D Agri and Vet 15: 21-28.

48. Sforcin JM (2007) Propolis and the immune system: a review. J Ethnopharmacol 113:1-14. [crossref]

49. Laxminarayan R, DuseA, Wattal C, Zaidi AK et al. (2013) Antibiotic resistance-the need for global solutions. The Lancet Infectious Dieases 13: 1057-1098. [crossref]

50. Boitor I, Bogdan ML, Ghitulescu C, Bogdan I (1994) Einsatz des Homoeopathika Lachesis compositum ad us. Vet. Bey puerperalen Uterusinfektionen und Ovarium compositium ad us. Vet Bei Ovarialzysten beim Rind Biol Tiermed 11: 44-49.
51. Dorenkamp B (1991) Lachesis compositum ad us. Vet zur Behandlung von Puerperalerkrankungen. Biol Tiermed 8: 36-421.

52. Doehring C and Sundrum A (2016) Efficacy of homeopahthy in livestock according to peer-reviewed publications from 1981-2014. Vet Rec 179: 628. [crossref]

53. Arlt S, Padberg W, Drillich M and Heuwieser W (2009) Efficacy of homeopathic remedies as prophylaxis of bovine endometritis. J Dairy Sci 92: 4945-4953. [crossref]

54. Enbergs H and Vorwig W (1995) Untersuchungen zur Praevention von postpartalen Zyklus- und Fruchtbarkeitsstoerungen bei Hochleistungskuehen durch die homoeopathischen Präparate Traumeel, Lachesis compositum und Carduus compositum. Biol Tiermed 95: 2-20.

55. Enbergs H and Sensen B (200) Zur Effizienz homoeopathischer Behandlungen chronischer. Endometritiden von Milchkuehen. Prakt Tierarzt 88: 534-543.

56. Hussain AM and Daniel RCW (1991) Bovine endometritis: current and future alternative therapy. J Vet Med A 38: 641-651. [crossref]

57. Nakao T, Moriyoshi M, Kawata K (1988) Effect of postpartum intrauterine treatment with $2 \%$ polyvinyl-pyrrolidone-iodine solution on reproductive efficiency in cows. Theriogenology 30: 1033-1043. [crossref]

58. Strube KR, Hühn R, Busch W, Werner E (1991) Ein Phagocytosetest zur Einschätzung der lokalen Abwehrsituation bei Endometritistherapie unter besonderer Berücksichtigung des Uterofertileinsatzes beim Rind. Dtsch Tierärtztl Wschr 98: 230234.

59. Heuwieser W, Tenhagen Ba, Tischer M, et al. (2000) Effect of three programmes for the treatment of endometritis on the reproductive performance of a dairy herd. Vet Rec 146: 338-341. [crossref]

60. Feldmann, M., S. Tenhagen genannt Emming and M. Hoedemaker (2005). "[Treatment of chronic bovine endometritis and factors for treatment success]." Dtsch Tierarztl Wochenschr 112(1): 10-16. [crossref]

61. Knutti B, Küpfer U, Busato A. Reproductive efficiency of cows with endometritis after treatment with intrauterine infusions of prostaglandin injections, or no treatment.

62. Carleton CL, Threlfall WR, Schwarze RA. 2008. Iodine in milk and serum following intrauteri infusion of Lugol's solution. Inter J Appl ResVet Med 6: 121-129.

63. McCaughan CJ, Laurie KW, Martin MC, Hooper MW (1984) Iodine in milk of cows after intrauterine infusion of Lugol's solution. Aust Vet J 61: 200-2001. [crossref]

64. Machado VS and Silva TH (2020) Adaptive immunity in the postpartum uterus: Potential use of vaccines to control metritis. Theriogenology 150: 201-209. [crossref]

65. Meira EBS, Ellington-Lawrence RD, Silva JCC, Higgins CH (2020) Recombinant protein subunit vaccine reduces puerpera metritis incidence an modulates the genital microbiome. J Dairy Sci 103: 7364-7376. [crossref]

66. Nolte O, Morscher J, Weiss HE, Sonntag HG (2001) Autovaccination of dairy cows to treat postpartum metritis caused by Actinomyces pyogenes. Vaccine 19: 3146-3153. [crossref]

67. Machado VS, de Souzas Bicalho ML, de Souza Meira EB, et al. (2014) Subcutaneous immunization with inactivated bacterial components and purified protein of E. coli, F. necrophorum, and T. pyogenes prevents puerperal metritis in Holstein dairy cows. Plos One 9: 1-11. [crossref]

68. Lamas GM (2016) da C Ensaio de vacina de rebanho contra agentes de metrite numa exploraçäo bovina leiteira. Unifersidada de Lisboa.

69. Freick M, Kunze A, Passarge O, Weber J, Geidel S (2017) Metritis vaccination in Holstein heifers using a herd-specific multivalent vaccine- Effect on uterine health and fertility in first lactation. Anim Reprod Sci 184: 160-171. [crossref]

70. Nagata S. 1989. Gene structure and function of granulocyte colony-stimulating factor. Bioassays. 10: 113-117. [crossref]

71. Zinicola M, Korzec H, Teixeira AGV, Ganda EK, Bringhenti L, Tomazi A, Gilbert RO, Bicalho (2018) Effect of pegbovigrastim administration on periparturient diseases, milk production, and reproductive performance of Hostein cows. J Dairy Sci 101: 1199-11217. [crossref]

72. Mitchell GB, Albright BN, Caswell JL (2003) Effect of interleukin-8 and granulocyte colony-stimulating factor on priming and activation of bovine neutrophils. Infect immune 71: 1643-1639. [crossref] 
73. Zinicola M, Batista CP, Bringhenti L, Meira EBS jr, Lima FS, et al. (2019a) Effect of recombinant bovine interleukin-8 (rbIL-8) treatment on health, metabolism and lactation performance in Holstein cattle IV: insulin resistance, dry matter intake, and blood parameters. J Dair Sci. 102: 10340-10359. [crossref]

74. Zinicola M, Bicahlo MLS, Santin T, Marques EC, Bisinotto RS, et al. (2019b) Effects of recombinant bovine interleukin-i (rbIL-8) treatment on health, metabolism, and lactation performance in Holstein cattle II: postpartum uterine health, ketosis, and milk production. J Dairy Sci 102: 10316-10328. [crossref]
75. McNeel AK, Reiter BC, Weigel D, Osterstock J, Di Croce FA (2017) Validation of genomic predictions for wellness traits in UH Holstein cows. J Dairy Sci 100: 91159124. [crossref]

76. Lopes F, Rosa G, Pinedo P, Santos JEP, et al. (2020) Genome-enable prediction for health traits using high-density SNP panel in US Holstein cattle. Anim Genet 51: 192199. [crossref]

77. Abdul-Hafeez MM, Abdul-Kadder HA, Sayed AM, Shehata SH (2019) Intrauterine honey infusion in Holstein Frisian cows with purulent endometritis. Inter $J$ Complementary and Alternative medicine 12:53-57.

\section{Citation:}

Lefebvre RC, Ali Torabi, Ali Bazzazan, Stock AE (2021) Alternative Treatments of Postpartum Uterine Diseases in Dairy Cows. Integr J Vet Biosci Volume 5(3): 1-7. 